About 35 per cent of the total will go to the biomedical sciences.

"The scale of this is really quite remarkable," says Friesen. Taken together with previously promised increases, the biomedical research budget will be close to Can $\$ 600$ million in five years, Friesen says. "Not so long ago it was a Can $\$ 230$ million commitment."

The proportion of younger to senior research chairs has not been decided. A committee, including the three research granting council presidents and David Strangway, president and chief executive officer of the Canada Foundation for Innovation, will work out the plan's details.

Louis Siminovitch, university professor emeritus at the University of Toronto, sees the initiative as "a great thing", but says "it is not clear what the rules are going to be. Salaries are very important for recruiting people," he adds. "But that's only a very small part of the brain drain. What determines whether a person goes to the United States is research resources."

Siminovitch says the plan "is a very big : step, but it may not be competitive with conditions in the United States. The most important message is that the federal government has awakened to the fact that they've got to do something for research and development."

Another investment of Can $\$ 11$ million : has also been announced by Strangway. He : says it will provide 124 researchers with the : infrastructure necessary to conduct 64 : research projects in 26 Canadian universities and colleges. Because the Canada Foundation for Innovation funds up to 40 per cent of : a project, this investment may trigger a further Can\$16.5 million from other funding partners.

\title{
US university fears allayed over access to research data
}

\section{Washington}

Final regulations covering access to university researchers' data under the Freedom of Information Act were published in Washington last week. They seem to have gone some way towards satisfying both sides in a bitter dispute over how far such access rights should reach.

The regulations, published by the White House Office of Management and Budget (OMB), will allow raw data to be accessed under the act if these data have been used as the basis for a range of government actions.

But data behind unpublished research results, intellectual property and clinical records of individuals will be exempt. This aspect of the regulations addresses some of the research community's greatest fears.

"We feel that OMB has done a pretty good job - perhaps a better job than seemed possible," says Bill Colglazier, executive officer of the National Academy of Sciences, which has opposed the move to use the act to gain access to researchers' data.

George Leventhal at the Association of American Universities, which represents leading research universities, says: "We think OMB has done well, and we're especially pleased that commercial and personal data will be exempted."

The regulations have also been accepted by Senator Richard Shelby (Republican, Alabama), who championed the legislation ordering OMB to draw them up a year ago. Shelby had objected to the last draft of the

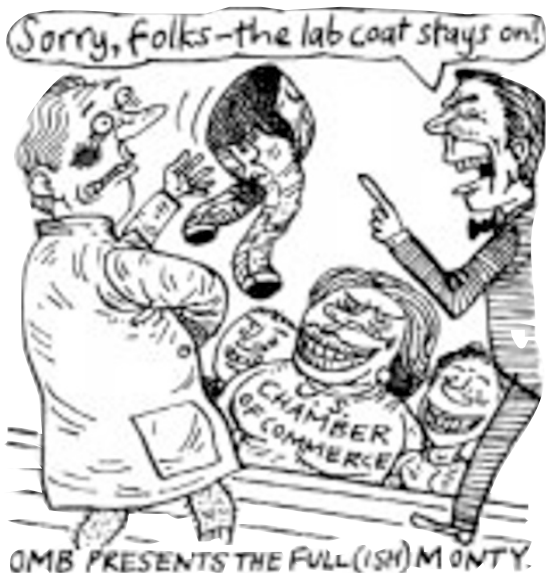

rules, published in August, saying that they allowed too many exemptions.

OMB acceded to Shelby's demand that the act should allow access to data behind all types of government action, not just federal regulations. It also removed a suggestion that the rules should apply only to research whose economic impact was expected to exceed $\$ 100$ million.

The final regulation "is a good first step to giving the American people access to the research and science used in federal policies that affect the lives of Americans each day", Shelby said in a statement.

US business has lobbied hard for access to research results under the act, seeing this as a means of assessing university studies used by the government as the basis for environmental and other regulations.

Colin Macilwain

\section{French students continue to turn away from science}

\section{Paris}

The number of students studying science in French universities and high schools has fallen for the fourth year in a row, according to figures released last week by the ministry for national education, research and technology.

Between 1995 and 1999, the number of first- and second-year university students or students entering for a diplôme d'études universitaires générales (DEUG) - in the sciences fell from 150,000 to 126,400 . The number of high-school students graduating with a science baccalaureate also dropped, from 143,200 to 125,000 .

Officials say the reduced interest at universities stems from the rise in popularity of classes préparatoires, which feed into the prestigious grandes écoles, as well as shorter degree programmes at technical colleges.

\begin{tabular}{|c|c|}
\hline \multicolumn{2}{|c|}{$\begin{array}{l}\text { Students in science DEUG programmes at } \\
\text { French universities }\end{array}$} \\
\hline Year & Number of students \\
\hline 1994-95 & 145,699 \\
\hline $1995-96$ & 149,688 \\
\hline 1996-97 & 143,759 \\
\hline 1997-98 & 134,447 \\
\hline 1998-99 & 126,403 \\
\hline
\end{tabular}

A survey distributed to 3,000 high-school students in April also shows that universities have a poor reputation among students, who think the quality of education is much lower than in the grandes écoles.

France is not alone when it comes to students straying from science. Statistics are similar elsewhere in Europe and the United States. The presidents of Europe's physics societies met last month in the United Kingdom to discuss the lack of students (see
Nature 401, 102; 1999). In Germany, for example, the number of first-year physics students has halved to 5,000 since 1991 .

Physics appears to be the worst hit of the sciences. "Students are turning away from the 'hard' sciences, especially physics, and are more attracted by biology and astronomy," says Claude Feuerstein, president of the University Joseph Fourier at Grenoble. "It's not that it is difficult to find a job after studying physics, in fact it may even be easier than after completing a biology degree."

Feuerstein hopes that reforms, including an emphasis on experimentation over theory and even a marketing campaign, will boost the image of physics and the other hard sciences. "Students need an attractive context and to know why they are learning this."

Heather McCabe 